\title{
LIFESTYLE OF PUBLIC TRANSPORT BUS DRIVERS AND FARE COLLECTORS
}

\section{Estilo de vida de motoristas e cobradores do transporte coletivo \\ Estilo de vida de condutores y cobradores de transporte colectivo}

\author{
Morgana Lunardi iD \\ Federal University of Santa Catarina (Universidade Federal de Santa Catarina - UFSC) - Florianópolis (SC) - Brazil \\ Everton Schilling \\ Federal University of Santa Catarina (Universidade Federal de Santa Catarina - UFSC) - Florianópolis (SC) - Brazil
}

Manoela Vieira Sousa iD

University of Porto (Universidade do Porto - U. Porto) - Porto - Portugal

Silas Nery de Oliveira iD

Federal University of Santa Catarina (Universidade Federal de Santa Catarina - UFSC) - Florianópolis (SC) - Brazil

Cíntia de la Rocha Freitas (iD

Federal University of Santa Catarina (Universidade Federal de Santa Catarina - UFSC) - Florianópolis (SC) - Brazil

\begin{abstract}
Objective: To analyze and compare the lifestyle of public transport drivers and fare collectors. Methods: Quantitative descriptive cross-sectional study of 88 bus drivers and 75 fare collectors from Florianópolis, Santa Catarina, Brazil. The Individual Lifestyle Profile questionnaire and anamnesis were used to determine the domain scores (nutrition, physical activity, preventive behavior, social relationship and stress control). Data collection took place from September to October 2016. The maximum significance level adopted was $5 \%(p \leq 0.05)$. The chi-squared test was used to check for associations between responses and job and the T-test for independent samples was used to compare variables between groups. Results: There was a statistical difference ( $p>0.001$ ) between bus drivers and fare collectors for age $(40.36 \pm 8.55 ; 31.30 \pm 8.68$ years), time on the job $(11.47 \pm 8.53 ; 6.14 \pm 5.46$ years) and time in the transport company $(12.8 \pm 6.64 ; 6.35 \pm 5.56$ years). There were no associations between the answers to the questions and the job $(p>0.05)$. With regard to the five domains, the workers presented negative behavior for nutrition ( $p=0.68)$ and physical activity $(p=0.50)$ and regular behavior for preventive behavior $(p=0.09)$, social relationships $(p=0.45)$ and stress control $(p=0.98)$, with no significant differences between groups. Conclusion: The comparison of bus drivers and fare collectors showed differences in age, time on the job and time in the company, but not in lifestyle. Moreover, public transport workers have a negative lifestyle profile in relation to nutrition and physical activity.
\end{abstract}

Descriptors: Life Style; Occupational Health; Health Promotion.

\section{RESUMO}

Objetivo: Analisar e comparar o estilo de vida dos motoristas e cobradores de tarifa do transporte público. Métodos: Estudo descritivo, quantitativo e transversal, com 88 motoristas de ônibus e 75 cobradores de tarifa de Florianópolis, Santa Catarina, Brasil. Para determinar os escores dos domínios (nutrição, atividade física, comportamento preventivo, relacionamento social e controle do estresse) aplicou-se o questionário Perfil Individual do Estilo de Vida e anamnese. A coleta de dados decorreu entre setembro e outubro de 2016. Considerou-se o nível de significância máximo assumido $5 \%(p \leq 0,05)$ e usou-se o teste qui-quadrado para avaliar a associação entre as respostas e a função do trabalho, e teste T para amostras independentes para comparar as variáveis entre os grupos. Resultados: Houve diferença estatística $(p>0,001)$ entre motoristas de ônibus e cobradores de tarifa para: idade $(40,36 \pm 8,55 ; 31,30 \pm 8,68$ anos), tempo na função $(11,47 \pm 8,53 ; 6,14 \pm 5,46$ anos) e tempo na empresa (12,8 26,64 ; $6,35 \pm 5,56$ anos), e não houve associação das respostas das perguntas com a função desempenhada $(p>0,05)$. Considerando os cinco domínios, os trabalhadores apresentaram comportamento negativo para nutrição $(p=0,68)$ e atividade física $(p=0,50)$, e comportamento regular para comportamento preventivo $(p=0,09)$, relações sociais $(p=0,45)$ e controle de estresse $(p=0,98)$, sem diferenças significativas entre grupos. Conclusão: Comparando-se os motoristas de ônibus e os cobradores de tarifa 
investigados, destaca-se que há diferenças na idade, no tempo na função e no tempo na empresa, mas não no estilo de vida, e que trabalhadores do transporte público possuem um perfil de estilo de vida negativo nos domínios de nutrição e atividade física.

Descritores: Estilo de Vida; Saúde do Trabalhador; Promoção da Saúde.

\section{RESUMEN}

Objetivo: Analizar y comparar el estilo de vida de los conductores y cobradores de tasas del transporte público. Métodos: Estudio descriptivo, cuantitativo y transversal con 88 conductores de autobuses y 75 cobradores de tarifa de Florianópolis, Santa Catarina, Brasil. Se aplicó el cuestionario Perfil Individual del Estilo de Vida y anamnesis para determinar las puntuaciones de los dominios (nutrición, actividad física, conducta de prevención, relacionamiento social y el control del estrés). La recogida de datos se dio entre septiembre y octubre de 2016. Se ha considerado el nivel de significancia máximo del 5\% ( $p \leq 0,05)$ y se ha utilizado la prueba de chi-cuadrado para evaluar la asociación entre las respuestas y la función del trabajo, la prueba $T$ para muestras independientes para comparar las variables entre los grupos. Resultados: Hubo diferencia estadística ( $p>0,001)$ entre

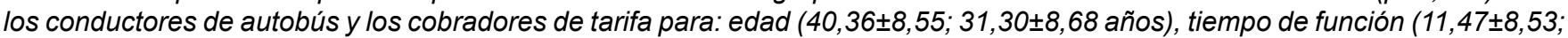
$6,14 \pm 5,46$ años) y tempo en la empresa $(12,8 \pm 6,64 ; 6,35 \pm 5,56$ años) y no hubo asociación entre las respuestas de las preguntas y la función realizada ( $p>0,05)$. Considerándose los cinco dominios, los trabajadores presentaron conducta negativa para nutrición $(p=0,68)$ y actividad física $(p=0,50)$, y conducta regular para la conducta de prevención $(p=0,09)$, las relaciones sociales $(p=0,45)$ y el control del estrés $(p=0,98)$, sin diferencias significativas entre los grupos. Conclusión: Comparándose los conductores de autobús y los cobradores de tarifa investigados, destacase que hay diferencias en la edad, en el tempo de función y en el tiempo de empresa pero no en el estilo de vida, y que los trabajadores del transporte público tiene un perfil de estilo de vida negativo para los dominios nutrición y actividad física.

Descriptores: Estilo de Vida; Salud Laboral; Promoción de la Salud.

\section{INTRODUCTION}

Lifestyle may be understood as a set of habits that reflect some behaviors, values and opportunities on people lives $^{(1)}$. An adequate lifestyle includes healthy eating habits, regular physical activity, preventive health care and other issues that account for a longer life expectancy and healthy aging ${ }^{(2)}$. It is well known that lifestyle is linked to wellbeing, in which long hours at work, inadequate body posture, physical inactivity, unhealthy eating habits, work shift and circadian cycle changes result in suppressed metabolic rate and overall decrease in metabolic expenditure, increased risk of obesity, hyperleptinemia, hyperlipidemia, hepatic steatosis, hyperglycemia and hypoinsulinemia ${ }^{(3)}$.

In that regard, the work environment must provide daily health practices to the workers to promote a better lifestyle, considering the amount of time they remain in it. Brazil's Ministry of Health and the Brazilian Institute of Geography and Statistics (Instituto Brasileiro de Geografia e Estatística - IBGE) have shown a negative association between workers in general and lifestyle patterns. Data from the National Health Research indicates that $70 \%$ of workers do not meet the recommendations for physical activity, $15.2 \%$ are smokers, $30 \%$ drink more than once a week and $6.2 \%$ have depression. In addition, the prevalence of obesity increases $17 \%-23 \%$ in men aged $55-64$ years and $55.6 \%$ of men are overweight ${ }^{(4)}$.

The prevalence of obesity among public transport workers has been high in both international ( $32 \%$ on average) and national studies $(24 \% \text { on average })^{(5)}$. This may be related to exposure to high levels of psychological stress ${ }^{(6-8)}$. Stressful working conditions combined with several hours working in a sitting position and other characteristics related to the work drivers and bus collectors perform have moved them into a risk group for health problems ${ }^{(9,10)}$. These workers constitute an extremely important professional category, especially in the most urbanized societies, due to the collective responsibility of their activity: the daily transport of passengers ${ }^{(7,8,10)}$.

Being a bus driver requires constant attention and driving skills: precision, self-control, fast reaction time and ability to interpret the surrounding environment in order to avoid accidents ${ }^{(7)}$. At the same time, the function of the onboard fare collector is to assist the bus driver in his working day ${ }^{(6)}$. Prolonged exposure to stress conditions causes them to experience musculoskeletal disorders and occupational diseases ${ }^{(11,12)}$. In this context, there are several studies that address different perspectives such as: violence against drivers ${ }^{(6)}$, health and work conditions ${ }^{(7,8)}$, cardiovascular risk taking into account race ${ }^{(10)}$ or workday ${ }^{(13)}$, prevalence of musculoskeletal pain ${ }^{(11)}$, food and anthropometric profile ${ }^{(14)}$, physiological aspects such as heart rate variability ${ }^{(15)}$, risk associated with work-related injuries ${ }^{(16)}$, metabolic and urinary profile ${ }^{(17)}$ or stress ${ }^{(18)}$.

The relevance of the aforementioned studies on the different perspectives is undisputed; however, in order to obtain a deeper understanding of these professionals, it is necessary to study these different perspectives related 
to lifestyle because the set of habitual actions, incompletely presented by previous studies, and lifestyle influence people's attitudes and values directly impacting quality of life ${ }^{(1)}$.

Thus, the greater the knowledge about factors that influence the lifestyle of these professionals, the more information is offered to deliver health promotion actions to these workers, such as the National Health Promotion Policy (Política Nacional de Promoção da Saúde - PNPS) ${ }^{(19)}$ and others. The strategies to achieve its objectives aim to build healthy and safe environments in addition to formulating policies that are committed to quality of life ${ }^{(19)}$, thus delivering multifocal interventions in the workplace aiming at the continuous improvement of workers' health ${ }^{(20)}$. In this context, the objective of this study was to analyze and compare the lifestyle of public transport drivers and fare collectors.

\section{METHODS}

This is a quantitative descriptive cross-sectional study. Data were collected at a public transportation company in Florianópolis, Santa Catarina, Brazil. Florianópolis has an estimated population of 500 thousand people and, just like other metropolitan centers of Brazil, it has suffered in the last decade with the increase of the density of vehicles on its highways ${ }^{(14)}$. This change in traffic, coupled with inadequate road infrastructure, has led to busy streets, poor comfort and agility in public transport, more angry people (drivers, fare collectors and passengers) and greater employee liability ${ }^{(14)}$. These facts can contribute to change the lifestyle of these workers who spend hours in traffic ${ }^{(14)}$.

Data collection took place between September and October 2016. All active employees were invited to participate in this study through informative posters placed on the internal message board, garage posts and in the boxes of the Downtown Integration Terminal (Terminal de Integração do Centro - TICEN) and the Tavares River Integration Terminal (Terminal de Integração do Rio Tavares - TIRIO).

After the invitation, the research instruments were delivered by the main researcher. At the beginning of each work shift, the employees were given a questionnaire, an anamnesis sheet and a consent form for completion. No pilot study was performed prior to data collection. The instruments were handed over to 362 employees. In order to assist employees in returning the questionnaires, the researchers distributed three boxes with information on deadline and blank questionnaires (in case the participant completed the questionnaire incorrectly and hence needed to complete it again). The ballot boxes were collected by the researcher the day after the deadline for delivery of the instruments (7 days).

The study inclusion criteria were: (1) to be fully engaged in the job; (2) to have completed the questionnaire properly; and (3) to return the questionnaire within 7 days after receiveing it. A total of 88 bus drivers (53.9\%) and 75 fare collectors (46.1\%) were included in the final sample. The power was calculated considering $\alpha=5 \%, \beta=80 \%$ and Chi-squared tests of association between job and lifestyle domains, thus resulting in a high effect size $(d=0.94)$ using the $\mathrm{G}^{*}$ Power software version 3.1.9.2.

Two instruments were used for data collection. The first instrument was an author-developed anamnesis sheet. During anamnesis, the participants provided some basic data for sample characterization: name; registration number (in the company); date of birth; age; sex; job (executive driver, conventional driver or collector); work shift and working hours; working hours (3h, $6 \mathrm{~h}$ or $6 \mathrm{~h}$ and $20 \mathrm{~min}$ ); physical activity practice and number of hours per week of physical activity; time on the job. We also assessed whether they perfomed another job and whether that was their first job.

The second instrument was the Individual Lifestyle Profile (ILP)(1), consisting of 15 questions that seek to evaluate five fundamental aspects of lifestyle: nutrition, physical activity, preventive behavior, social relationship and stress control. Each component is made up of three questions in which the participant must assign a number to each question ranging from (0) absolutely not part of your lifestyle, (1) sometimes corresponding to your behavior, (2) almost always true for your behavior and (3) the statement is always true in your daily life as part of your lifestyle.

The mean value on each question was used to evaluate the lifestyle of bus drivers and fare collectors. The options ranged from 0 to 3 and scores below 1 were considered negative behavior, that is, the behavior posed health risks and affected the quality of life. Scores between 1 and 1,99 were considered regular and scores between 2 and 3 indicated positive behavior ${ }^{(1)}$. The values on each component were then summed to analyze the lifestyle profile. The scale ranged from 0 to 9 , where 0 to 3,99 indicated negative lifestyle, 4 to 6,99 indicated regular lifestyle and 7 to 9 suggested positive lifestyle ${ }^{(21)}$.

Data are presented as means and standard deviations (SD) and were screened for normal distribution using the Shapiro-Wilk test. The chi-squared test was used to check for significant associations between the answers and the job performed and the independent t-test was used to compare the scores between drivers and collectors. 
The significance threshold for all statistical analyses was set at an alpha of 0.05 . All the statistical analyses were performed using IBM SPSS, version 17 (SPSS Inc., Chicago, IL, USA). All the participants signed a consent form approved by the Research Ethics Commiteee of the Federal University of Santa Catarina (Universidade Federal de Santa Catarina) (Approval No. 2.047.156).

\section{RESULTS}

Participants were 163 public transport employees from Florianópolis, Santa Catarina, Brazil. A total of 88 bus drivers $(53.9 \%)$ and 75 fare collectors $(46.1 \%)$ were included in the final sample. There was a prevalence of men $(88 ; 100 \%)$ among the bus drivers who participated in the study and their mean age was $40.36( \pm 8.55)$ years. There was also a prevalence of men (72; $96.0 \%)$ among the fare collectors who participated in the study and their mean age was $31.30( \pm 8.68)$ years. There was a significant difference in age $(p<0.001)$ between the groups of workers who participated in the study. Bus drivers were older than fare collectors (mean difference of 9.06 years).

Most workers did not practice physical activity regularly (bus drivers $=59.09 \%$; fare collectors $=53.33 \%$ ) - both bus drivers ( $\mathrm{No}=59.1 \%$ and $\mathrm{Yes}=40.9 \%$ ) and fare collectors ( $\mathrm{No}=53.3 \%$ and $\mathrm{Yes}=46.7 \%)$. Bus drivers practiced an average of $5.67( \pm 5.3)$ hours of physical activity weekly and fare collectors practiced an average of $4.22( \pm 3.1)$ hours of physical activity weekly, with no significant differences between the groups. The types of physical activity practiced by the workers were soccer, walking, various combat sports, running, cycling, swimming and strength training.

Table I presents the percent values and/or the mean and standard deviation for the work characteristics. Most bus drivers $(64.77 \%)$ and fare collectors $(64 \%)$ worked the morning shift, were not on their first jobs (bus drivers = $85.23 \%$; fare collectors $=94.67 \%$ ) and did not have an additional job (bus drivers $=75 \%$; fare collectors $=68 \%$ ).

Table I - Work-related characteristics of collective transport workers from Florianópolis, Santa Catarina, Brazil, 2016.

\begin{tabular}{lcc}
\hline Work-related characteristics & $\begin{array}{c}\text { Bus drivers } \\
\mathbf{n}(\%)\end{array}$ & $\begin{array}{c}\text { Fare collectors } \\
\mathbf{n}(\%)\end{array}$ \\
\hline Daily workload & & $4(5.33 \%)$ \\
3 hours & $3(3.41 \%)$ & $3(4 \%)$ \\
6 hours & $1(1.14 \%)$ & $68(90.67 \%)$ \\
6 hours and 20 minutes & $84(95.45 \%)$ & $27(36 \%)$ \\
Work shift & & $48(64 \%)$ \\
Morning & $29(35.23 \%)$ & $4(5.33 \%)$ \\
Afternoon & $59(64.77 \%)$ & $71(94.67 \%)$ \\
First job? & & $24(32 \%)$ \\
Yes & $13(14.77 \%)$ & $51(68 \%)$ \\
No & $75(85.23 \%)$ & \\
Additional job? & & $22(25 \%)$ \\
Yes & $66(75 \%)$ & \\
No & & \\
\hline
\end{tabular}

There was a significant difference in time on the job and in time in the company $(p<0.001)$. Bus drivers had been on the job for longer compared with fare collectors (11.47 \pm 8.53 years and $6.14 \pm 5.46$ years, respectively) and had also been working in the company for longer (12.8 \pm 6.64 years and $6.35 \pm 5.56$ years, respectively) (Table II).

Table III shows the most frequent answer and percent values for each ILP question. There were no associations between the job performed and the answers in the ILP questionnaire.

Table II - Working time characteristics of public transport workers from a company in Florianópolis, Santa Catarina, Brazil, 2016.

\begin{tabular}{lccc}
\hline Working time characteristics & $\begin{array}{c}\text { Bus drivers } \\
\text { Mean } \pm \text { SD }\end{array}$ & $\begin{array}{c}\text { Fare collectors } \\
\text { Mean } \pm \text { SD }\end{array}$ & $\begin{array}{c}\text { p-value } \\
\text { (T test) }\end{array}$ \\
\hline Time (years) on the same job & $11.47 \pm 8.5$ & $6.14 \pm 5.5$ & $<0.001^{*}$ \\
Time (years) of employment in the company & $12.8 \pm 6.6$ & $6.35 \pm 5.6$ & \\
\hline
\end{tabular}

*Significant difference between bus drivers and fare collectors $(p<0.05)$; SD: standard deviation 
Table III - Association of the answer in each question of the Individual Lifestyle Profile (ILP) questionnaire with the job performed in a company from Florianópolis, Santa Catarina, Brazil, 2016.

\begin{tabular}{|c|c|c|c|c|}
\hline & & Bus drivers - $\mathrm{n}(\%)$ & Fare collectors - $\mathrm{n}(\%)$ & $\begin{array}{c}\text { p-value } \\
\text { (Chi-squared) }\end{array}$ \\
\hline & 1 & Sometimes - 40 (45.5) & Sometimes - 39 (52) & 0.85 \\
\hline \multirow[t]{3}{*}{ Nutrition } & 2 & Sometime - 37 (42) & Sometimes - 27 (36) & 0.37 \\
\hline & 3 & Always - 25 (28.4) & Sometimes - 20 (26.7) & 0.96 \\
\hline & 4 & Absolutely not - 46 (52.3) & Absolutely not - 31 (41.3) & 0.47 \\
\hline \multirow[t]{3}{*}{ Physical activity } & 5 & Absolutely not - 41 (46.6) & Absolutely not - 23 (30.7) & 0.08 \\
\hline & 6 & Absolutely not - 30 (34.1) & Sometimes - 25 (33.3) & 0.56 \\
\hline & 7 & Absolutely not - 38 (43.2) & Absolutely not - 37 (49.3) & 0.82 \\
\hline \multirow[t]{3}{*}{ Preventive behavior } & 8 & Absolutely not - 47 (53.4) & Absolutely not - 39 (52) & 0.18 \\
\hline & 9 & Always - 70 (79.5) & Always - 48 (64) & 0.11 \\
\hline & 10 & Always - 63 (71.6) & Always - 44 (58.7) & 0.29 \\
\hline \multirow[t]{3}{*}{ Social relationship } & 11 & Always - 29 (33) & Almost always - 32 (42.7) & 0.06 \\
\hline & 12 & Almost always and Always - 23 (26.1) & Sometimes - 29 (38.7) & 0.15 \\
\hline & 13 & Always - 47 (53.4) & Always - 33 (44) & 0.60 \\
\hline \multirow[t]{2}{*}{ Stress control } & 14 & Sometimes - 30 (34.1) & Almost always - 34 (45.3) & 0.22 \\
\hline & 15 & Always - 29 (33) & Always - 25 (33.3) & 0.99 \\
\hline
\end{tabular}

The workers presented negative behavior for the components nutrition ( 3.53 and $3.67 ; p=0.682)$ and physical activity (3.32 and $3.61 ; p=0.503$ ) and regular behavior for the components preventive behavior (4.77 and 4.21; $p=0.092$ ), social relationships ( 5.76 and $5.48 ; p=0.448$ ) and stress control ( 5.29 and $5.24 ; p=0.980$ ), with no significant differences between bus drivers and fare collectors (Table IV).

Table IV - Mean score assigned by collective transport workers (bus drivers and fare collectors) to each component of the Individual Lifestyle Profile (ILP) questionnaire. Florianópolis, Santa Catarina, Brazil, 2016.

\begin{tabular}{lcccc}
\hline & $\begin{array}{c}\text { Bus drivers } \\
\text { (Mean } \pm \text { SD) }\end{array}$ & $\begin{array}{c}\text { Fare collectors } \\
\text { (Mean } \pm \text { SD) }\end{array}$ & Classification & $\begin{array}{c}\text { p-value } \\
\text { (T test) }\end{array}$ \\
\hline Nutrition & $3.53 \pm 2.04$ & $3.67 \pm 2.07$ & Negative & 0.682 \\
Physical activity & $3.32 \pm 2.90$ & $3.61 \pm 2.66$ & Negative & 0.503 \\
Preventive behavior & $4.77 \pm 2.10$ & $4.21 \pm 2.10$ & Regular & 0.092 \\
Social relationship & $5.76 \pm 2.35$ & $5.49 \pm 2.11$ & Regular & 0.448 \\
Stress control & $5.28 \pm 2.31$ & $5.29 \pm 2.38$ & Regular & 0.980 \\
\hline
\end{tabular}

\section{DISCUSSION}

Men represented almost the entirety of the workers on the jobs analyzed in this study. This finding is similar to previous studies focused on these professions ${ }^{(5,8,11,12)}$ and it seems to be related to the danger that surrounds the job considering the number of robberies and road traffic accidents ${ }^{(6)}$. In addition, the mean age of bus drivers was higher than that of fare collectors, probably due the hierarchy of jobs in the workplace and to the fact that in order to get a bus driving license (license $D$ ) in Brazil, the applicant must be 21 years of age or older and have a minimum of two years of license $B$ (vehicles that do not exceed 8 seats) or one year of license $C$ (cargo vehicles) ${ }^{(7,11)}$.

In our study, the percentages of occurrence for the five components of the lifestyle did not differ between the two jobs and the most troubling results in both groups were found in the nutrition and physical activity parameters. With regard to the consumption of five portions of fruits or vegetables per day, many respondents answered sometimes, which indicates that these professionals have an inadequate nutritional profile and thus need to change their eating habits. Such habit may be explained by the little time they have to eat and the lack of access to healthy food at the final stop of the bus line, which has been previously reported by other studies ${ }^{(14,23)}$.

Moreover, over half of the participants did not comply with the recommended minimum of 150 minutes of physical activity per week for health promotion ${ }^{(7)}$. Other studies have reported high percentages of workers who did not practice physical activity, with mean values ranging from 25 to $6 \%^{(5-7,13,24)}$, which corroborates our findings (bus drivers $59.09 \%$; fare collectors $-53.33 \%$ ). Regardless of the job, the participants exhibited levels of physical inactivity higher than the value observed for the male Brazilian population (35 to $40 \%$ are physically inactive) $)^{(25)}$. 
The working conditions to which bus drivers and fare collectors are subjected include many hours in a sitting position and repeated movements, especially among drivers ${ }^{(7,14)}$. The exhaustive work routine associated with a lack of interest in or instructions about the benefits and motivation are possibly the main factors that support the low levels of physical activity ${ }^{(5,10,23)}$. A previous study revealed that before starting the job $29.1 \%$ of bus drivers did not achieve the minimum recommended amount of physical activity and after being promoted to bus drivers this level increased to $56.4 \%{ }^{(14)}$.

Chronic exposure to these circumstances added to the psychological stress of the job and unfavorable eating conditions tend to put the worker at an increased risk of depression or anxiety disorders and overweight and obesity, thereby giving way to the development of cardiometabolic disorders such as cardiovascular disease and type II diabetes ${ }^{(5,10,23,24,26)}$. In order to reduce these risks, the PNPS ${ }^{(19)}$ includes actions targeted at healthy eating, regular physical activity, smoking prevention and control, and reduction of the abuse of alcohol and other drugs. These actions are strongly based on ILP domains ${ }^{(19)}$.

Another way to obtain health benefits for professionals is through Occupational Health Promotion Programs ${ }^{(27)}$. The implementation of health promotion policies and educational interventions can promote benefits to workers, companies and governmental expenditures on workers' health ${ }^{(7,9,12,14,24-26)}$. Some strategies could encourage the workers to walk and cycle to work and establish healthy eating habits, such as providing safe and convenient bike parking, ensuring appropriate and acceptable toilet facilities, providing sufficient time to eat healthily and creating a lifestyle awareness project ${ }^{(9,12)}$. The adoption of these new alternatives - promoting specific education, vocational training and health promotion processes - are in accordance with the principles and values expressed in the Health Promotion Policy for workers, managers and citizens ${ }^{(19)}$.

The analysis of the preventive behavior parameter showed that the workers interviewed had a low compliance with the control of blood pressure and cholesterol levels. These results are in agreement with recent data that showed that nearly one-third $(31 \%)$ of Brazilian men do not systematically monitor their health condition and do not seek help for disease prevention ${ }^{(28)}$. The stressors inherent to the profession - which is considered one of the most unhealthy - and the ineffective coping responses ${ }^{(29,30)}$ intensify the lack of care for physical and mental health.

Still with regard to preventive behavior, most drivers (79.5\%) and fare collectors (64\%) reported wearing seat belt, respecting traffic laws and not drinking before or during work. These are important factors since disasters and incidents involving public transport workers are considered public health problems ${ }^{(31)}$. Alcohol abuse has been reported by a low percentage of public transport workers, regardless of the region of Brazil, ranging from 13 to $14 \%^{(5,6)}$.

In a previous study, the prevalence of alcohol abuse and dependence was higher among workers who reported no participation in social activities ${ }^{(31)}$. This information corroborates our findings since positive results were found regarding alcohol consumption, making friends, and overall relationship satisfaction. Most workers (33\%) reported having a balance between work and leisure, which probably improves stress control.

Long sitting periods, high percentages of physical inactivity and poor nutritional quality were conditions reported in this study and corroborate data from other studies with this population in several Brazilian cities ${ }^{(5,7,13,32)}$. Studies evaluating the lifestyle of bus drivers and fare collectors using the ILP are scarce, which limits the possibility of comparisons with our results. However, it was possible to make comparisons of data on physical inactivity, poor diet, lack of health care, good social relationship and stress control with other studies that did not use a validated instrument ${ }^{(5-8,10,13,18)}$.

New studies on different domains of quality of life over the years of work should be conducted. Moreover, there is a need for studies to measure the effect of the implementation of physical and psychological intervention programs, such as active commuting, regular physical activity, improvement of working conditions (such as the adequacy of work breaks) and improvement of traffic and safety conditions by public sector bodies ${ }^{(5,7,13)}$.

Some limitations of the present study must be considered, such as the fact all the people interviewed worked in the same company in Florianópolis, Santa Catarina, Brazil. Additionally, the study design did not include the measurement of socioeconomic status; however, as the type of work was limited to collective transport, that effect was probably minimized.

\section{CONCLUSION}

The comparison of the bus drivers and fare collectors interviewed showed there are differences in age, time on the job and time in the company, but not in lifestyle. Public transport workers have a negative lifestyle profile with regard to nutrition (reduced fruit and vegetable intake and increased fat intake) and physical activity (inactive displacement and failure to meet minimum health recommendations). 


\section{CONFLICTS OF INTEREST}

The authors declare that there is no conflict of interest regarding this study.

\section{CONTRIBUTIONS}

Morgana Lunardi contributed to study conception and design; data acquisition, analysis and interpretation; writing and/or revision of the manuscript. Everton Schilling contributed to study conception and design; data acquisition, analysis and interpretation; Manoela Vieira Sousa and Silas Nery de Oliveira: contributed to data analysis and interpretation; writing and/or revision of the manuscript. Cíntia de la Rocha Freitas contributed to study conception and design; writing and/or revision of the manuscript.

\section{REFERENCES}

1. Nahas MV, Barros MVG, Francalacci V. O Pentáculo do Bem-Estar: base conceitual para avaliação do estilo de vida de indivíduos ou grupos. Rev Bras Ativ Fís Saúde [Internet]. 2000 [accessed on 2019 Oct 10];5(2):4859. Available from: http://rbafs.org.br/RBAFS/article/view/1002/1156

2. McPhee JS, French DP, Jackson D, Nazroo J, Pendleton N, Degens H. Physical activity in older age: perspectives for healthy ageing and frailty. Biogerontology [Internet]. 2016 [accessed on 2019 Oct 10];17(3):567-80. Available from: https://www.ncbi.nlm.nih.gov/pmc/articles/PMC4889622/

3. Bae S-A, Fang MZ, Rustgi V, Zarbl H, Androulakis IP. At the interface of lifestyle, behavior, and circadian rhythms: metabolic implications. Front Nutr [Internet]. 2019 [accessed on 2019 Oct 10];6(132):1-17. Available from: https://www.frontiersin.org/articles/10.3389/fnut.2019.00132/full

4. Ministério da Saúde (BR). Mais de $70 \%$ dos trabalhadores não se exercitam regularmente [Internet]. Brasília: Ministério da Saúde; 2016 [accessed on 2019 Oct 10]. Available from: http://www.saude.gov.br/noticias/ svs/24356-mais-de-70-dos-trabalhadores-nao-se-exercitam-regularmente

5. Souza LPS, Assunção AA, Pimenta AM. Fatores associados à obesidade em rodoviários da Região Metropolitana de Belo Horizonte, Minas Gerais, Brasil. Rev Bras Epidemiol [Internet]. 2019 [accessed on 2019 Oct 10];22:1-15. Available from: http://www.scielo.br/scielo.php?script=sci_arttext\&pid=S1415$790 \times 2019000100424$

6. Assunção AA, Medeiros AM. Violence against metropolitan bus drivers and fare collectors in Brazil. Rev Saúde Pública [Internet]. 2015 [accessed on 2019 Oct 10];49(11):1-10. Available from: http://www.scielo.br/ scielo.php?script=sci_arttext\&pid=S0034-89102015000100207

7. Moura AB Neto, Silva MC. Diagnóstico das condições de trabalho, saúde e indicadores do estilo de vida de trabalhadores do transporte coletivo da cidade de Pelotas RS. Rev Bras Ativ Fís Saúde [Internet]. 2012 [accessed on 2019 Oct 10];5(17):347-58. Available from: http://rbafs.org.br/RBAFS/article/view/2174/pdf6

8. Battiston M, Cruz RM, Hoffmann MH. Condições de trabalho e saúde de motoristas de transporte coletivo urbano. Estud Psicol [Internet]. 2006 [accessed on 2019 Oct 10];11(3):333-43. Available from: http://www. scielo.br/scielo.php?script=sci_arttext\&pid=S1413-294X2006000300011

9. Chung Y-S, Wong J-T. Developing effective professional bus driver health programs: An investigation of self-rated health. Accid Anal Prev [Internet]. 2011 [accessed on 2019 Oct 10];43(6):2093-103. Available from: https://www.sciencedirect.com/science/article/pii/S0001457511001618?via\%3Dihub

10. Winkleby MA, Ragland DR, Fisher JM, Syme SL. Excess risk of sickness and disease in bus drivers: a review and synthesis of epidemiological studies. Int J Epidemiol [Internet]. 1988 [accessed on 2019 Oct 10];17(2):255-62. Available from: https://academic.oup.com/ije/article-abstract/17/2/255/792424?redirectedFro $\mathrm{m}=$ fulltext

11. Simões MR, Assunção AA, Medeiros AM. Dor musculoesquelética em motoristas e cobradores de ônibus da Região Metropolitana de Belo Horizonte, Brasil. Ciênc Saúde Colet [Internet]. 2018 [accessed on 2019 Oct 10];23(5):1363-74. Available from: http://www.scielo.br/scielo.php?script=sci_abstract\&pid=S1413$81232018000501363 \&$ Ing=pt\&nrm=iso 
12. Ghasemi S, Pirzadeh A. Effectiveness of educational physical activity intervention for preventive of musculoskeletal disorders in bus drivers. Int J Prev Med [Internet]. 2019 [accessed on 2019 Oct 10];10(132):1-15. Available from: https://www.ncbi.nlm.nih.gov/pmc/articles/PMC6710914/

13. Souza MGC, Silva CL, Pirschner F, Contarato GL, Braga LW, Torres VM. Correlação de alguns hábitos de estilo de vida e jornada de trabalho com a pressão arterial aferida em motoristas de transporte coletivo urbano. Rev Bras Med Trab [Internet]. 2009 [accessed on 2019 Oct 10];5(6):28-38. Available from: http://rbmt. org.br/details/150/pt-BR/correlacao-de-alguns-habitos-de-estilo-de-vida-e-da-jornada-de-trabalho-com-apressao-arterial-aferida-em-motoristas-de-transporte-coletivo-urbano

14. Faria BK, Amorim G, Vancea DMM. Perfil alimentar e antropométrico dos motoristas de ônibus da empresa de transporte coletivo Jotur/Palhoça-SC. Rev Bras Obesidade Nutr Emagrecimento [Internet]. 2007 [accessed on 2019 Oct 10];1(1):11-20. Available from: http://www.rbone.com.br/index.php/rbone/article/view/2

15. Tarane K, Fredrick J, Gaur GS, Aruna R, Dhanalakshmi Y. Heart rate variability among long distance bus drivers after a night shift. Int J Physiol [Internet]. 2019 [accessed on 2019 Oct 10];7(2):50-4. Available from: https://www.indianjournals.com/ijor.aspx?target=ijor:ijp2\&volume=7\&issue=2\&article=010

16. Wei C, Gerberich SG, Ryan AD, Alexander BH, Church TR, Manser M. Risk factors for unintentional occupational injury among urban transit bus drivers: a cohort longitudinal study. Ann Epidemiol [Internet]. 2017 [accessed on 2019 Oct 10];27(12):763-70. Available from: https://www.sciencedirect.com/science/article/pii/ S104727971630309X?via\%3Dihub

17. Pradhan CK, Chakraborty I, Thakur S, Mukherjee S. Physiological and metabolic status of bus drivers. In: Ray G, Iqbal R, Ganguli A, Khanzode V, editors. Ergonomics in Caring for People. [Switzerland]: Springer Singapore, 2018. p. 161-7.

18. Almeida NDV. Considerações acerca da incidência do estresse em motoristas profissionais. Rev Psicol [Internet]. 2010 [accessed on 2019 Oct 10];1(1):75-84. Available from: http://www.periodicos.ufc.br/ psicologiaufc/article/view/49

19. Ministério da Saúde (BR), Secretaria de Vigilância em Saúde, Secretaria de Atenção à Saúde. Política Nacional de Promoção da Saúde: revisão da Portaria MS/GM nº 687, de 30 de março de 2006 [Internet]. Brasília: Ministério da Saúde; 2014 [accessed on 2019 Out 10]. Available from: https://www.conass.org.br/wpcontent/uploads/2014/11/NT-18-2014-Politica-de-Promoc\%CC\%A7a\%CC\%83o-da-Sau\%CC\%81de.pdf

20. Carvalho AFS, Dias EC. Promoção da saúde no local de trabalho: revisão sistemática da literatura. Rev Bras Promoç Saúde [Internet]. 2012 [accessed on 2019 Oct 10];25(1):116-26. Available from: https://periodicos. unifor.br/RBPS/article/view/2219

21. Silva EM, Sousa AC, Kumpel C, Souza JS, Porto EF. Estilo de vida de indivíduos usuários do sistema único de saúde. LifeStyle J [Internet]. 2018 [accessed on 2019 Oct 10];5(2):61-75. Available from: https://revistas. unasp.edu.br/LifestyleJournal/article/view/1073

22. Guterres A, Duarte D, Siqueira FV, Silva MC. Prevalência e fatores associados a dor nas costas dos motoristas e cobradores da cidade de Pelotas-RS. Rev Bras Ativ Fís Saúde [Internet]. 2011 [accessed on 2019 Oct 10];3(16):240-45. Available from: http://rbafs.org.br/RBAFS/article/view/603

23. French SA, Harnack L, Toomey TL, Hannan PJ. Association between body weight, physical activity and food choices among metropolitan transit workers. Int J Behav Nutr Phys Act [Internet]. 2007 [accessed on 2019 Oct 10];4(52):1-12. Available from: https://www.ncbi.nlm.nih.gov/pmc/articles/PMC2200661/

24. Pinto ECT, Bueno MB. Avaliação nutricional e hábitos alimentares de motoristas de transporte público do município de Jundiaí-SP. Rev Assoc Bras Nutr [Internet]. 2019 [accessed on 2019 Oct 10]:10(1):53-8. Available from: https://www.rasbran.com.br/rasbran/article/view/1136

25. Silva ICM, Mielke GI, Bertoldi AD, Arrais P, Luiza VL, Mengue SS, et al. Overall and leisure-time physical activity among brazilian adults: national survey based-on the global physical activity questionnaire. J Phys Act Health [Internet]. 2018 [accessed on 2019 Oct 10];15(3):212-8. Available from: https://journals.humankinetics. com/doi/10.1123/jpah.2017-0262

26. Morais RA, Souza DT, Ferron AJT, Souza CT, Francisqueti FV. Caracterização do padrão alimentar e do estado nutricional dos motoristas de transporte coletivo da cidade de Bauru-SP. Rev Bras Obesidade Nutr 
Emagrecimento [Internet]. 2018 [accessed on 2019 Oct 10];12(71):293-300. Available from: http://www.rbone. com.br/index.php/rbone/article/view/699

27. Brito ECO, Martins CO. Percepção dos participantes de programa de Ginástica Laboral sobre flexibilidade e fatores reçacionados a um estilo de vida saudável. Rev Bras Promoç Saúde [Internet]. 2012 [accessed on 2019 Oct 10];25(4):445-54. Available from: https://periodicos.unifor.br/RBPS/article/view/2547

28. Ministério da Saúde (BR). Um terço dos homens não acompanha o estado de saúde [Internet]. Brasília: Ministério da Saúde; 2016 [accessed on 2019 Oct 10]. Available from: http://www.saude.gov.br/noticias/ agencia-saude/25093-um-terco-dos-homens-nao-acompanha-o-estado-de-saude

29. Barbosa LAS, Andrade ALM, Oliveira LG, Micheli D. Prevalência do consumo de substâncias psicotrópicas por motoristas de ônibus urbano: uma revisão sistemática. SMAD Rev Eletrônica Saúde Mental Alcool Drog [Internet]. 2018 [accessed on 2019 Oct 10];14(4):234-44. Available from: http://pepsic.bvsalud.org/pdf/smad/ v14n4/07.pdf

30. Soares EFG, Pardo LS, Costa AAS. Evidências da interrelação trabalho/ocupação e hipertensão arterial sistêmica: uma revisão integrativa. Rev Bras Promoç Saúde [Internet]. 2017 [accessed on 2019 Oct 10];30(1):102-9. Available from: https://periodicos.unifor.br/RBPS/article/view/4437

31. Cunha NO, Giatti L, Assunção GA. Factors associated with alcohol abuse and dependence among public transport workers in the metropolitan region of Belo Horizonte. Int Arch Occup Envirnm Health [Internet]. 2016 [accessed on 2019 Oct 10];89(6):881-90. Available from: https://dx.doi.org/10.1007/s00420-016-1124-8

32. Ramos BH, Almeida MFC, Ribeiro JA, Silveira CA. Condições de vida, trabalho e saúde de motoristas de transporte de cargas. Rev Enferm UFPE [Internet]. 2018 [accessed on 2019 Oct 10];12(1):150-9. Available from: http://www.scielo.br/pdf/epsic/v11n3/11.pdf

\author{
Mailing address: \\ Morgana Lunardi \\ Centro de Desportos da Universidade Federal de Santa Catarina \\ Av. César Seara - Carvoeira \\ Campus Trindade \\ CEP: 88.040-900 - Florianópolis - SC - Brasil \\ E-mail: morganalunardi.edf@gmail.com
}

How to cite: Lunardi M, Schilling E, Sousa MV, Oliveira SN, Freitas CR. Lifestyle of public transport bus drivers and fare collectors. Rev Bras Promoç Saúde. 2019;32:9733. 